\title{
Thermal properties of solid solution of manganese (II) - cobalt (II) diphosphate
}

\author{
N.M.Antraptseva, N.V.Solod \\ National University of Life and Environmental Sciences of Ukraine, \\ 17 Heroiv Oborony St., 03041 Kyiv, Ukraine
}

\section{Received September 7, 2016}

The composition, temperature ranges of formation and thermal stability of heat treatment products of solid solution with the general formula $\left(\mathrm{Mn}_{1-x} \mathrm{Co}_{x}\right)_{2} \mathrm{P}_{2} \mathrm{O}_{7} \cdot 5 \mathrm{H}_{2} \mathrm{O}$ $(0<x \leq 0.41)$ in the range of $298-1273 \mathrm{~K}$ were determined. The cation nature effect on them was concretized. The end product of the heat treatment - solid solution of anhydrous diphosphates with composition $\beta-\left(\mathrm{Mn}_{1-x} \mathrm{Co}_{x}\right)_{2} \mathrm{P}_{2} \mathrm{O}_{7}, 0<x \leq 0.41$ (space group $C 2 / m$, $Z=2$ ) - was identified. It was shown, that its formation is realized in two directions. The first of them is realized by 69-66\% due to dehydration of initial crystallohydrate $\left(\mathrm{Mn}_{1-x} \mathrm{Co}_{x}\right)_{2} \mathrm{P}_{2} \mathrm{O}_{7} \cdot 5 \mathrm{H}_{2} \mathrm{O}$. According to the second direction, 31-34 \% $\beta-\left(\mathrm{Mn}_{1-x} \mathrm{Co}_{x}\right)_{2} \mathrm{P}_{2} \mathrm{O}_{7}$ is formed through solid phase reaction of the intermediate dehydration products. The sequence of thermal and structural transformations, which accompany the heat treatment of the diphosphates $\left(\mathrm{Mn}_{1-x} \mathrm{Co}_{x}\right)_{2} \mathrm{P}_{2} \mathrm{O}_{7} \cdot 5 \mathrm{H}_{2} \mathrm{O}(0<x \leq 0.41)$, was proposed.

Keywords: diphosphates, manganese(II), cobalt(II), solid solution, thermal properties, dehydration.

Определены состав, температурные интервалы образования и термической стабильности продуктов термообработки твердого раствора общей формулы $\left(\mathrm{Mn}_{1-x} \mathrm{Co}_{x}\right)_{2} \mathrm{P}_{2} \mathrm{O}_{7} \cdot 5 \mathrm{H}_{2} \mathrm{O}(0<x \leq 0.41)$ в интервале 298-1273 К. Конкретизировано влияние на них природы катиона. Идентифицирован конечный продукт термообработки - твердый раствор безводных дифосфатов состава $\beta-\left(\mathrm{Mn}_{1-x} \mathrm{Co}_{x}\right)_{2} \mathrm{P}_{2} \mathrm{O}_{7}, 0<x \leq 0,41$ (пр. гр. $C$ $2 / m, Z=2$ ). Показано, что образование его происходит одновременно по двум направлениям. Первое из них реализуется на 69-66 \% в результате дегидратации исходных кристаллогидратов $\left(\mathrm{Mn}_{1-x} \mathrm{Co}_{x}\right)_{2} \mathrm{P}_{2} \mathrm{O}_{7} \cdot 5 \mathrm{H}_{2} \mathrm{O}$. Согласно второму, 31-34\% $\beta-\left(\mathrm{Mn}_{1-x} \mathrm{Co}_{x}\right)_{2} \mathrm{P}_{2} \mathrm{O}_{7}$ образуется благодаря твердофазному взаимодействию промежуточных продуктов обезвоживания. Предложена последовательность термических и структурных преобразований, которые сопровождают термообработку дифосфатов $\left(\mathrm{Mn}_{1-x} \mathrm{Co}_{x}\right)_{2} \mathrm{P}_{2} \mathrm{O}_{7} \cdot 5 \mathrm{H}_{2} \mathrm{O}(0<x \leq 0,41)$.

Термічні властивості твердого розчину манган(II) i кобальт(II) дифосфатів. Н.М.Антрапиева, Н.В.Солод.

Визначено склад, температурні інтервали утворення і термічної стабільності продуктів термообробки твердого розчину загальної формули $\left(\mathrm{Mn}_{1-x} \mathrm{Co}_{x}\right)_{2} \mathrm{P}_{2} \mathrm{O}_{7} \cdot 5 \mathrm{H}_{2} \mathrm{O}$ $(0<x \leq 0,41)$ в інтервалі 298-1273 К. Конкретизовано вплив на них природи катіона. Ідентифіковано кінцевий продукт термообробки - твердий розчин безводних дифосфатів складу $\beta-\left(\mathrm{Mn}_{1-x} \mathrm{Co}_{x}\right)_{2} \mathrm{P}_{2} \mathrm{O}_{7} .0<x \leq 0,41$ (пр. гр. $\left.C 2 / m, Z=2\right)$. Показано, що утворення його відбувається одночасно за двома напрямками. Перший з них реалізується на 69-66\% внаслідок дегідратації вихідних кристалогідратів $\left(\mathrm{Mn}_{1-x} \mathrm{Co}_{x}\right)_{2} \mathrm{P}_{2} \mathrm{O}_{7} \cdot 5 \mathrm{H}_{2} \mathrm{O}$. Відповідно до другого, 31-34\% $\beta-\left(\mathrm{Mn}_{1-x} \mathrm{Co}_{x}\right)_{2} \mathrm{P}_{2} \mathrm{O}_{7}$ утворюється завдяки твердофазної взаємодії проміжних продуктів зневоднення. Запропоновано послідовність термічних i структурних перетворень, що супроводжують термообробку дифосфатів $\left(\mathrm{Mn}_{1-x} \mathrm{Co}_{x}\right)_{2} \mathrm{P}_{2} \mathrm{O}_{7} \cdot 5 \mathrm{H}_{2} \mathrm{O}(0<x \leq 0.41)$. 


\section{Introduction}

The products of full and partial dehydration of divalent metals hydrated diphosphate, including manganese (II) - cobalt (II), are widely used as the basis for obtaining of the modern inorganic materials: active catalysts, pigments, optical glass, enamel, heat-sensitive paint, luminescent materials etc. $[1-4]$.

Rational choice of optimal modes of crystalline treating, which provide the obtaining of new materials of a high quality and functionality has to be grounded by the necessary knowledge of composition, temperature ranges of formation and thermal stability of the products, of their partial and full dehydration, the sequence of thermal and structural changes that accompany them.

Thermal behavior of manganese (II) cobalt (II) diphosphate was considered during the study of vibrational spectra of diphosphate $\left(\mathrm{Mn}_{2-x} \mathrm{Co}_{x}\right)_{2} \mathrm{P}_{2} \mathrm{O}_{7} \cdot 5 \mathrm{H}_{2} \mathrm{O}$ and the products received after treating at the temperature of $1000^{\circ} \mathrm{C}$ [5]. In particular, the temperature of thermal effects was established and showed on the differential thermal analysis curve, the number of stages of weight loss and anhydrous diphosphate were determined.

However, there is no data in the study [5] on the composition and thermal properties of partial dehydration products obtained in a wide temperature range of heat treatment of hydrated manganese (II) - cobalt (II) diphosphate. Moreover, given in [5] thermal research data cannot be considered as fully proper because objects used for the research were non-isostructural diphosphate. Diphosphate $\left(\mathrm{Mn}_{2-x} \mathrm{Co}_{x}\right)_{2} \mathrm{P}_{2} \mathrm{O}_{7} \cdot 5 \mathrm{H}_{2} \mathrm{O}$, in which the value of $x=0-$ it is manganese (II) diphosphate pentahydrate with composition $\mathrm{Mn}_{2} \mathrm{P}_{2} \mathrm{O}_{7} \cdot 5 \mathrm{H}_{2} \mathrm{O}$, diphosphate with $x=2$ - it is cobalt (II) diphosphate, which crystallizes with 6 water molecules $\mathrm{Co}_{2} \mathrm{P}_{2} \mathrm{O}_{7} \cdot 6 \mathrm{H}_{2} \mathrm{O}$. Therefore, their products of thermal treatment were identified as diphosphates with different structures $\mathrm{Mn}_{2} \mathrm{P}_{2} \mathrm{O}_{7}$ and $\alpha-\mathrm{Co}_{2} \mathrm{P}_{2} \mathrm{O}_{7}$.

Information on the systematic study of thermal properties of solid solution of manganese (II) and cobalt (II) diphosphate with some specification of composition and its treated products properties under a wide range of temperatures is absent for now in the scientific literature.

The purpose of the present work is to investigate the thermal properties of solid solution of manganese (II) and cobalt (II) diphosphate of general formula $\left(\mathrm{Mn}_{1-x} \mathrm{Co}_{x}\right)_{2} \mathrm{P}_{2} \mathrm{O}_{7} \cdot 5 \mathrm{H}_{2} \mathrm{O}(0<x \leq 0.41)$ and to determine the composition, temperature ranges of formation and thermal stability of products of its thermal treatment considering a quantitative assessment of cation nature influence.

\section{Experimental}

Solid solution of hydrated manganese (II) - cobalt (II) diphosphate of general formula $\left(\mathrm{Mn}_{1-x} \mathrm{Co}_{x}\right)_{2} \mathrm{P}_{2} \mathrm{O}_{7} \cdot 5 \mathrm{H}_{2} \mathrm{O} \quad(0<x \leq 0.41)$ was obtained by common precipitation of cations $\mathrm{Mn}^{2+}$ and $\mathrm{Co}^{2+}$ by diphosphate-ion $\mathrm{P}_{2} \mathrm{O}_{7}{ }^{4-}$, under interaction with mixture of $0.1 \mathrm{~mole} / \mathrm{l}$ of water solutions of manganese (II) and cobalt (II) sulphate with solution of potassium diphosphate, taken in the molar ratio of $K=\mathrm{Mn}^{2+} / \mathrm{Co}^{2+}=0.43 \leq K \leq 9.00$, $n=\mathrm{P}_{2} \mathrm{O}_{7}^{4-} / \sum \mathrm{Mn}, \mathrm{Co}^{2+}=0.2$, similar to that described in [6]. The saturated solid solution with composition $\left(\mathrm{Mn}_{0.59} \mathrm{Co}_{0.41}\right)_{2} \mathrm{P}_{2} \mathrm{O}_{7} \cdot 5 \mathrm{H}_{2} \mathrm{O}$ was used as the study main object. Content of the ingredients in $\left(\mathrm{Mn}_{0.59} \mathrm{Co}_{0.41}\right)_{2} \mathrm{P}_{2} \mathrm{O}_{7} \cdot 5 \mathrm{H}_{2} \mathrm{O}$ is, wt. $\%: \mathrm{Mn}-17.19$, Co $-13.08, \mathrm{P}-16.47$, $\mathrm{H}_{2} \mathrm{O}-23.93$. Thermoanalytical researches of the solid solution diphosphates with different content of cobalt, which changed from 3.15 to $13.08 \%$, were carry out for study the influence of cation nature.

Thermal properties were studied in the temperature range of $298-1273 \mathrm{~K}$ in $\mathrm{dy}$ namic (derivatograph Q-1500 D, platinum crucible with lid, standard sample freshly calcined $\mathrm{Al}_{2} \mathrm{O}_{3}$, the sample weight 100-300 $\mathrm{mg}$, heating rate $-5^{\circ} / \mathrm{min}$, accuracy of temperature is $\pm 5^{\circ} \mathrm{C}$ ) and quasi-isothermal (conical holder of the samples, the sample weight $-200 \mathrm{mg}$, heating rate is $3^{\circ} / \mathrm{min}$ ) heating regimes.

The products of thermal treatment were obtained similarly $[7,8]$ at the temperatures corresponding to heating effects on DTA curves. The complex analytical methods: chemical, X-ray (powder diffractometer DRON-4M connected with the computing complex on the basis of a computer of IBM $\mathrm{PC} / \mathrm{AT} 486$ type, $\mathrm{Fe} \mathrm{K} \alpha$ radiation, internal standard $\mathrm{NaCl}$ ), IR spectroscopy (IR spectrometer Nexus-470, range of $400-$ $4000 \mathrm{~cm}^{-1}$, at $20^{\circ} \mathrm{C}$ and $-190^{\circ} \mathrm{C}$, sample pressed into $\mathrm{KBr}$ tablets) was used for identification of the thermal treatment products. Anionic composition of products of partial and full dehydration was established using the method of quantitative paper chromatography, according to [9]. 

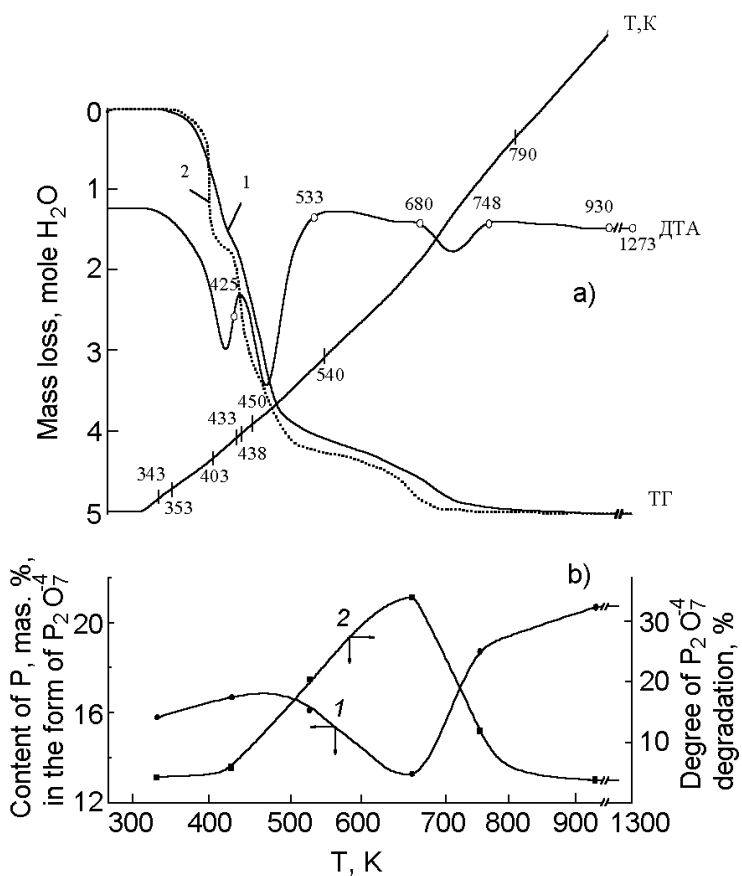

Fig. 1. Results of complex research of thermal properties of $\left(\mathrm{Mn}_{0.59} \mathrm{Co}_{0.41}\right)_{2} \mathrm{P}_{2} \mathrm{O}_{7} \cdot 5 \mathrm{H}_{2} \mathrm{O}: \mathrm{a}-$ curves of thermal analysis in dynamic (1) and quasi-isothermal (2) heating regimes; b - temperature dependences of phosphorus content in treating products (1) and degree of degradation (2), -o- - place of sampling for analysis.

\section{Results and discussion}

According to the results of thermo analytical research, $\left(\mathrm{Mn}_{0.59} \mathrm{Co}_{0.41}\right)_{2} \mathrm{P}_{2} \mathrm{O}_{7} \cdot 5 \mathrm{H}_{2} \mathrm{O}$ is stable when heated in air atmosphere at $5^{\circ} / \mathrm{min}$ up to $343 \mathrm{~K}$. Further increase in temperature is recorded on the DTA curve by three endothermic effects in the following ranges: $343-438 \mathrm{~K}, 438-533 \mathrm{~K}$ and 680-748 K (Fig. 1). In the TG curve (thermogravimetric) weight loss corresponds to the thermal effects; the weight loss process takes place in three main stages and is 8.68 , 10.96 and 1.46 mas \%. (or 1.81, 2.29 and 0.38 moles of $\mathrm{H}_{2} \mathrm{O}$ ). Final 0.11 mole of $\mathrm{H}_{2} \mathrm{O}$ are removed in a rather wide temperature range of $748-930 \mathrm{~K}$.

Thermal resistance of $\left(\mathrm{Mn}_{0.59} \mathrm{CO}_{0.41}\right)_{2} \mathrm{P}_{2} \mathrm{O}_{7} \cdot 5 \mathrm{H}_{2} \mathrm{O}$ increases up to $353 \mathrm{~K}$ in terms of quasi-isothermal heating (Q-regime), when the partial pressure of water vapor over the sample is almost equilibrium. Dehydration of $\left(\mathrm{Mn}_{0.59} \mathrm{CO}_{0.41}\right)_{2} \mathrm{P}_{2} \mathrm{O}_{7} \cdot 5 \mathrm{H}_{2} \mathrm{O}$ is performed in three stages in these conditions and ends at $790 \mathrm{~K}$ (Fig. 1). The first (remove of $1.74 \mathrm{~mole}_{2} \mathrm{O}$ ) is in the range of 353$425 \mathrm{~K}$ at almost constant temperature (403 K). The peculiarity of the second stage

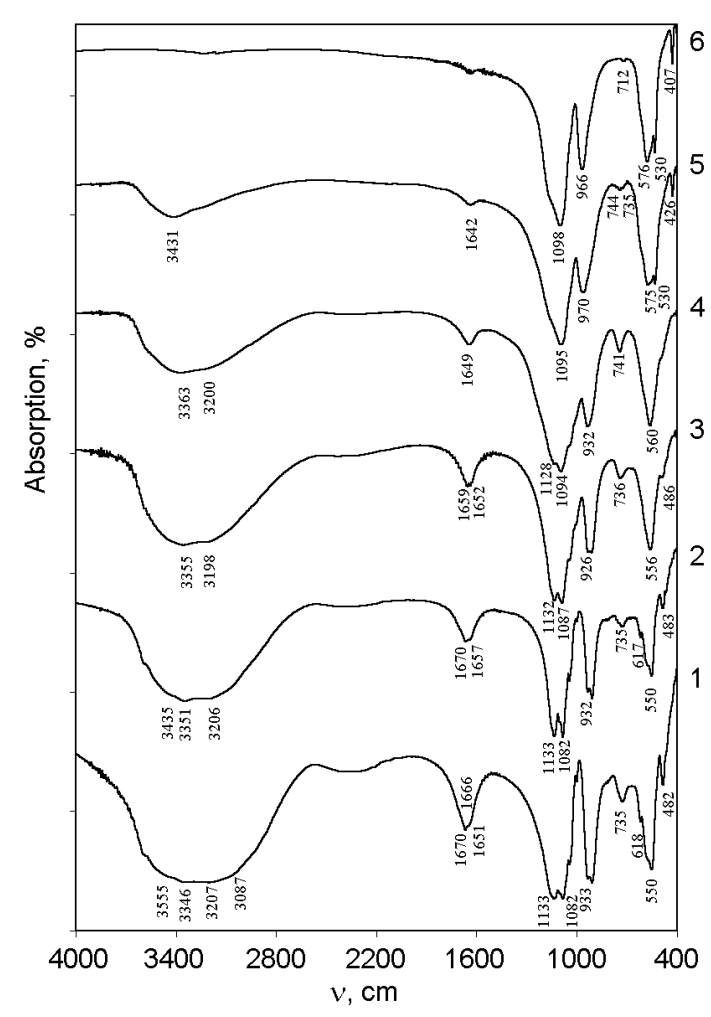

Fig. 2. IR spectrum of treating products of $\left(\mathrm{Mn}_{0.59} \mathrm{Co}_{0.41}\right)_{2} \mathrm{P}_{2} \mathrm{O}_{7} \cdot 5 \mathrm{H}_{2} \mathrm{O}$, obtained at 343 (1) 425 (2), 533 (3), 680 (4), 748 (5), 930$1237 \mathrm{~K}(6)$.

is two different mechanisms of removing $\mathrm{H}_{2} \mathrm{O}$ part in the TG curve. Loss of weight corresponding to 1.46 mole $\mathrm{H}_{2} \mathrm{O}$ is registered in a rather narrow temperature range of $425-450 \mathrm{~K}$. The next 0.9 moles of $\mathrm{H}_{2} \mathrm{O}$ are removed in the range of $450-540 \mathrm{~K}$ without temperature stabilization. Interpretation of the thermal curves for each of them, according to the classification of processes with quasi-isothermal conditions, shows the formation of compounds with variable hydrate in the range of 353-450 K. Heat treatment at the high temperatures $(450-540 \mathrm{~K})$ leads to complications of diphosphate dehydration with the processes of destruction and anionic condensation.

The result of complex analysis of the products of thermal treatment of $\left(\mathrm{Mn}_{0.59} \mathrm{Co}_{0.41}\right)_{2} \mathrm{P}_{2} \mathrm{O}_{7} \cdot 5 \mathrm{H}_{2} \mathrm{O}$ shows that in dynamic heating conditions up to $425 \mathrm{~K}$, structure of initial crystallohydrate is preserved in whole. The diphosphate with less hydrate is formed in consequence of removing of 1.62 moles of $\mathrm{H}_{2} \mathrm{O}$. According to chemical analysis, its composition corresponds to diphosphate of $\left(\mathrm{Mn}_{0.59} \mathrm{Co}_{0.41}\right)_{2} \mathrm{P}_{2} \mathrm{O}_{7} \cdot 3.38 \mathrm{H}_{2} \mathrm{O}$. In the IR spectrum the presence of 
Table 1. Anionic composition of treating products $\left(\mathrm{Mn}_{0.59} \mathrm{Co}_{0.41}\right)_{2} \mathrm{P}_{2} \mathrm{O}_{7} \cdot 5 \mathrm{H}_{2} \mathrm{O}$

\begin{tabular}{|c|c|c|c|c|c||}
\hline \multirow{2}{*}{ Temperature, K } & \multirow{2}{*}{$\begin{array}{c}\text { Mass loss, mole } \\
\mathrm{H}_{2} \mathrm{O}\end{array}$} & \multirow{2}{*}{$P_{\text {gen }}$, mas. \% } & \multicolumn{3}{|c||}{ Phosphorus content, mas. \%, as } \\
\cline { 4 - 6 } & - & 16.42 & mono- & di- & triphosphate \\
\hline 343 & 1.62 & 17.74 & $1.0 *$ & 16.8 & - \\
425 & 4.10 & 20.24 & 4.0 & 16.1 & 0.2 \\
533 & 4.55 & 20.93 & 5.4 & 13.3 & 2.2 \\
680 & 4.89 & 21.43 & 2.0 & 18.7 & 0.7 \\
748 & 5.00 & 21.57 & $0.8 *$ & 20.7 & - \\
930 & - & &
\end{tabular}

* Result of diphosphate hydrolysis during sample preparation to analysis.

$\left(\mathrm{Mn}_{0.59} \mathrm{Co}_{0.41}\right)_{2} \mathrm{P}_{2} \mathrm{O}_{7} \cdot 3.38 \mathrm{H}_{2} \mathrm{O}$ is registered with absorption changes associated with vibrations of water molecules. In the spectrum field, which characteristic for valence vibrations of OH-group (3000-3600 $\mathrm{cm}^{-1}$ ) and deformation vibrations of $\mathrm{H}_{2} \mathrm{O}$ molecules (1630-1680 $\left.\mathrm{cm}^{-1}\right)$, the intensity and amount of absorption bands reduce (Fig. 2). The nature of absorption in the field of diphosphate anion vibrations is preserved. Spectral analysis indicates realization of molecular mechanism of removal of 1.62 moles of crystallized water from the structure of

$$
\begin{gathered}
\left(\mathrm{Mn}_{0.59} \mathrm{CO}_{0.41}\right)_{2} \mathrm{P}_{2} \mathrm{O}_{7} \cdot 5 \mathrm{H}_{2} \mathrm{O} \frac{343-425 K}{-1.62 \text { moles of } \mathrm{H}_{2} \mathrm{O}} \rightarrow \\
\left(\mathrm{Mn}_{0.59} \mathrm{CO}_{0.41}\right)_{2} \mathrm{P}_{2} \mathrm{O}_{7} \cdot 3.38 \mathrm{H}_{2} \mathrm{O} .
\end{gathered}
$$

The thermal treating of $\left(\mathrm{Mn}_{0.59} \mathrm{Co}_{0.41}\right)_{2} \mathrm{P}_{2} \mathrm{O}_{7} \cdot 5 \mathrm{H}_{2} \mathrm{O}$ in the range of 438-533 $\mathrm{K}$ is accompanied by the more complex thermal and structural transformations. Product of the partial dehydration which is formed by removal of 4.10 moles of $\mathrm{H}_{2} \mathrm{O}$ under these conditions, actually is heterophased mixture of crystalline and $\mathrm{X}$-ray amorphous phases. The crystalline phases, which were identified by the most intense diffraction reflections $\left(d_{\text {exp. }} 1.18\right.$, $0.890,0.326 \mathrm{~nm}$ with intensity at 81,100 and $45 \%$, respectively), and the data of [10] are diphosphate mono- and tree-hydrate. Their number in composition of thermal treatment products under these conditions is $79.5 \%$ of the total phosphorus content (Table 1).

According to the results of quantitative chromatography methods, mono and some amount of triphosphate are X-ray amorphous (Table 1). The monophosphate formation (up to 4.0 mas. \%) is a result of destruction of diphosphate anion which is accompanied by destruction of bridge bond<smiles>CCC(C)OP(=O)(OC)[Te](C)(C)OP(=O)(OC)OC</smiles>

Scheme 1.

P-O-P according to the scheme 1 . Changes taking place in composition of the heat treatment products at $438-533 \mathrm{~K}$ in the IR spectrum are recorded in the whole spectral range (Fig. 2). In the area of anion sublattice vibration the most sensitive to changes of diphosphate anion transformation to be absorption in the range of $620-$ $400 \mathrm{~cm}^{-1}$, which is characteristic for the deformation vibrations of bond P-O. Not only the intensity, but also the number of bands $v(\mathrm{OH})$ decrease in then area of water molecules vibrations, and there absorption maximum are shifted.

The processes of destruction and anionic condensation of the diphosphate anion, which started in the treating products of $\left(\mathrm{Mn}_{0.59} \mathrm{Co}_{0.41}\right)_{2} \mathrm{P}_{2} \mathrm{O}_{7} \cdot 5 \mathrm{H}_{2} \mathrm{O}$ at $438-533 \mathrm{~K}$, become more intensive with the further heating up to $680 \mathrm{~K}$. Totally X-ray amorphous phase, formed during these processes, differs with its complexity (Table 1). Content of monophosphate in it increases at 5.4 mas. \%, diphosphate - decreases at 13.3 mas. \%. So it is formed the phosphate with the higher level of polycondensation - triphosphate with linear structure of the anion (2.2 mas. \%). The degree of destruction of the diphosphate anion reaches its maximum value and is $34 \%$, that is evidence of participation of the monophosphate in the process of anionic condensation (Fig. 1b).

Regarding the mechanism of triphosphate formation, the analysis of quantita- 
tive changes in ratios of di- and monophosphate allows to claim about its active participation in the process of condensing with the both mono- and diphosphate anion:

$$
\begin{gathered}
2 \mathrm{HPO}_{4}^{2-} \rightarrow \mathrm{P}_{2} \mathrm{O}_{7}^{4-}+\mathrm{H}_{2} \mathrm{O}, \\
4 \mathrm{HPO}_{4}^{2-}+\mathrm{H}_{2} \mathrm{P}_{2} \mathrm{O}_{7}^{2-} \rightarrow 2 \mathrm{P}_{3} \mathrm{O}_{10}^{5-}+3 \mathrm{H}_{2} \mathrm{O} .
\end{gathered}
$$

On the other hand, the presence of the condensed phosphates in composition of the thermal treating products is a result of realization of dissociative mechanism of water remove, which complicates the dehydration reaction with the process of intramolecular hydrolysis. Spectroscopic indication of its possible course is the presence of $\mathrm{v}(\mathrm{OH})$ bands in the low-frequency range of the IR spectrum (3200-3000 $\left.\mathrm{cm}^{-1}\right)$. Analysis of changes in the entire spectral pattern and the wave numbers of $\mathrm{v}(\mathrm{OH})$ maximum in the IR spectrum of the treated products of $\left(\mathrm{Mn}_{0.59} \mathrm{Co}_{0.41}\right)_{2} \mathrm{P}_{2} \mathrm{O}_{7} \cdot 5 \mathrm{H}_{2} \mathrm{O}$, obtained at 533 and $680 \mathrm{~K}$, indicates a strengthening of $\mathrm{H}$-bonds in their structure that exist between the water molecules and phosphate tetrahedrons (Fig. 2). They correlate with the $v(\mathrm{OH})$ bands with wave numbers $3198 \mathrm{~cm}^{-1}$ and $3200 \mathrm{~cm}^{-1}$, the energy of $\mathrm{H}$ bonds for them is 33.4 and $33.3 \mathrm{~kJ} / \mathrm{mole}$. This points to possibility of protolytic dissociation of water molecules and proton transfer through the strongest $\mathrm{H}$-bond to the anion with formation of protonated and basic groups of types $\mathrm{P}-\mathrm{O}-\mathrm{H}$ and $\mathrm{M}-\mathrm{OH}$. The formation of the triphosphate at $680 \mathrm{~K}$ is the consequence of further thermal transformations of the protonated groups in accordance with polycondensation mechanism, that can be shown as follows:

$$
\begin{gathered}
2(n-1) \mathrm{Mn}_{0.59} \mathrm{Co}_{0.41} \mathrm{HPO}_{4}+ \\
+\mathrm{Mn}_{0.59} \mathrm{Co}_{0.41} \mathrm{H}_{2} \mathrm{P}_{2} \mathrm{O}_{7} \rightarrow \\
\rightarrow(n-1)\left(\mathrm{Mn}_{0.59} \mathrm{Co}_{0.41}\right)_{(\mathrm{n}+2) / 2} \mathrm{P}_{\mathrm{n}} \mathrm{O}_{3 \mathrm{n}+1}+\mathrm{nH}_{2} \mathrm{O} .
\end{gathered}
$$

For the further heating of $\left(\mathrm{Mn}_{0.59} \mathrm{Co}_{0.41}\right)_{2} \mathrm{P}_{2} \mathrm{O}_{7} \cdot 5 \mathrm{H}_{2} \mathrm{O}$ up to $748 \mathrm{~K}$ (total weight loss is 4.89 moles of $\mathrm{H}_{2} \mathrm{O}$ ) the anionic composition of the thermal treatment products becomes more simple: the triphosphates are almost absent, the number of monophosphate decreases (at 2.0 mas. \%), diphosphate content increases at 18.7 mas. \% . (Table 1). X-rays fixed the start of formation of the crystal structure of anhydrous $\beta-\left(\mathrm{Mn}_{0.59} \mathrm{Co}_{0.41}\right)_{2} \mathrm{P}_{2} \mathrm{O}_{7}$, which is identified with the emergence of the most intense diffraction reflections $\left(d_{\text {exp. }} 0.305,0.294\right.$,
$0.256,0.214,0.206 \mathrm{~nm})$, similar to the known for $\beta-\mathrm{Mn}_{2} \mathrm{P}_{2} \mathrm{O}_{7}[11,12]$. Data processing suggests that its formation is the result of solid state interactions of the treated products intermediates by this scheme:

$$
\begin{aligned}
& \left(\mathrm{Mn}_{0.59} \mathrm{Co}_{0.41}\right)_{(\mathrm{n}+2) / 2} \mathrm{P}_{\mathrm{n}} \mathrm{O}_{3 \mathrm{n}+1}+ \\
+ & (n-2) / 2 \mathrm{Mn}_{0.59} \mathrm{Co}_{0.41} \mathrm{O} \rightarrow \\
\rightarrow & n / 2 \beta-\left(\mathrm{Mn}_{0.59} \mathrm{Co}_{0.41}\right)_{2} \mathrm{P}_{2} \mathrm{O}_{7}
\end{aligned}
$$

In the IR spectrum, these solid phase transformations are fixed with significant changes in the whole spectral range. The intensity of the $v(\mathrm{OH})$ an $\delta\left(\mathrm{H}_{2} \mathrm{O}\right)$ bands significantly reduces, the number of valence vibration bands of finite $\mathrm{OH}_{3}$-group of anion $\mathrm{P}_{2} \mathrm{O}_{7}^{4-}$ decreases. The $v_{s}(\mathrm{POP})$ band at $741 \mathrm{~cm}^{-1}$ split into two - at 744 and $735 \mathrm{~cm}^{-1}$, indicating the emergence in a the structure of two types of anions $\mathrm{P}_{2} \mathrm{O}_{7}^{4-}$ with different P-O-P angles (Fig. 2). Singlet $\delta(P O)$ band at $560 \mathrm{~cm}^{-1}$ becomes a doublet with maxima at $576,530 \mathrm{~cm}^{-1}, \delta(\mathrm{PO})$ band at $426 \mathrm{~cm}^{-1}$ appears, which is characteristic for anhydrous $\beta-\mathrm{Mn}_{2} \mathrm{P}_{2} \mathrm{O}_{7}$ [13].

Crystallization of the final product of thermal treatment $-\beta-\left(\mathrm{Mn}_{0.59} \mathrm{CO}_{0.41}\right)_{2} \mathrm{P}_{2} \mathrm{O}_{7}$ is completely finished with the removal of the final amount of water $(0.11$ mole of $\mathrm{H}_{2} \mathrm{O}$ in the range of $748-930 \mathrm{~K}$ ). In the IR spectrum of the diphosphate obtained at $930 \mathrm{~K}$, the bands of water molecules absorption are completely absent (Fig. 2). The transformation of two $v_{s}$ (POP) bands into singlet observe in the area of the diphosphate anion vibration, which significantly moves further in the low-frequency area of the spectrum (up to $712 \mathrm{~cm}^{-1}$ ). This indicates the presence of the crystallographically equivalent diphosphate anions in the structure of $\beta-\left(\mathrm{Mn}_{0.59} \mathrm{Co}_{0.41}\right)_{2} \mathrm{P}_{2} \mathrm{O}_{7}$, the angle $\mathrm{P}-\mathrm{O}-\mathrm{P}$ is straightened slightly in it. As a result, configuration of the anion $\mathrm{P}_{2} \mathrm{O}_{7}{ }^{4-}$ approaches centrosymmetric one, known for $\beta$-diphosphate $[13,14]$, but the angle $\mathrm{P}-\mathrm{O}-\mathrm{P}$ is not of $180^{\circ}$.

Further heating of the anhydrous diphosphate up to $1273 \mathrm{~K}$ leads to increased intensity of diffraction reflections on the $\mathrm{X}$-ray photograph of $\beta-\left(\mathrm{Mn}_{0.59} \mathrm{Co}_{0.41}\right)_{2} \mathrm{P}_{2} \mathrm{O}_{7}$ (Fig. 3), which indicates the improvements in its structure and thermal stability in the range of $930-1273 \mathrm{~K}$.

The sequence of processes occurring in the thermal treatment products of $\left(\mathrm{Mn}_{0.59} \mathrm{Co}_{0.41}\right)_{2} \mathrm{P}_{2} \mathrm{O}_{7} \cdot 5 \mathrm{H}_{2} \mathrm{O}$ and their qualita- 
Table 2. Crystallographic data for diphosphates $\beta-\left(\mathrm{Mn}_{1-x} \mathrm{Co}_{x}\right)_{2} \mathrm{P}_{2} \mathrm{O}_{7}, 0<x \leq 0.41$ (monoclinic, sp. gr. $C 2 / m, Z=2$ )

\begin{tabular}{||c|c|c|c|c|c||}
\hline \multirow{2}{*}{$\begin{array}{c}\text { Composition of } \\
\beta \text {-diphosphates }\end{array}$} & \multicolumn{3}{|c|}{ Unit cell parameters, nm } & \multirow{2}{*}{$\beta,^{\circ}$} & \multirow{2}{*}{$V, \mathrm{~nm}^{3}$} \\
\cline { 2 - 5 } & $a$ & $b$ & $c$ & \\
\hline $\left.\mathrm{Mn}_{0.85} \mathrm{Co}_{0.05}\right)_{2} \mathrm{P}_{2} \mathrm{O}_{7}$ & $0.6635(3)$ & $0.8590(4)$ & $0.4543(3)$ & 102.71 & $0.2526(6)$ \\
$\left(\mathrm{Mn}_{0.90} \mathrm{Co}_{0.10}\right)_{2} \mathrm{P}_{2} \mathrm{O}_{7}$ & $0.6634(3)$ & $0.8589(3)$ & $0.4539(4)$ & 102.77 & $0.2525(7)$ \\
$\left(\mathrm{Mn}_{0.79} \mathrm{Co}_{0.21}\right)_{2} \mathrm{P}_{2} \mathrm{O}_{7}$ & $0.6618(6)$ & $0.8579(4)$ & $0.4531(5)$ & 102.85 & $0.2514(9)$ \\
$\left(\mathrm{Mn}_{0.70} \mathrm{Co}_{0.30}\right)_{2} \mathrm{P}_{2} \mathrm{O}_{7}$ & $0.6603(4)$ & $0.8519(3)$ & $0.4529(4)$ & 103.00 & $0.2484(8)$ \\
$\left(\mathrm{Mn}_{0.59} \mathrm{Co}_{0.41}\right)_{2} \mathrm{P}_{2} \mathrm{O}_{7}$ & $0.6594(1)$ & $0.8481(2)$ & $0.4521(9)$ & 103.03 & $0.2463(8)$ \\
\hline
\end{tabular}

tive composition are the same for the diphosphate solid solution of $\left(\mathrm{Mn}_{1-x} \mathrm{Co}_{x}\right)_{2} \mathrm{P}_{2} \mathrm{O}_{7} \cdot 5 \mathrm{H}_{2} \mathrm{O}(0<x \leq 0.41)$ of different composition. The cation nature influences the temperature ranges of formation and thermal stability of the both initial crystallohydrates, and the products of partial and full dehydration. According to the data obtained, they are maximum for diphosphate solid solution of $\left(\mathrm{Mn}_{1-x} \mathrm{Co}_{x}\right)_{2} \mathrm{P}_{2} \mathrm{O}_{7} \cdot 5 \mathrm{H}_{2} \mathrm{O}(0<x \leq 0.41)$ with the highest content of cobalt (II).

Comparative analysis of the products composition, which formed at similar stages of the heat treatment of diphosphate with a minimum content of cobalt (II) $\left(\mathrm{Mn}_{0.85} \mathrm{Co}_{0.05}\right)_{2} \mathrm{P}_{2} \mathrm{O}_{7} \cdot 5 \mathrm{H}_{2} \mathrm{O}-$ and saturated solid solution - $\left(\mathrm{Mn}_{0.59} \mathrm{Co}_{0.41}\right)_{2} \mathrm{P}_{2} \mathrm{O}_{7} \cdot 5 \mathrm{H}_{2} \mathrm{O}$, shows that the process of destruction and changes of the crystal structure of $\left(\mathrm{Mn}_{0.59} \mathrm{Co}_{0.41}\right)_{2} \mathrm{P}_{2} \mathrm{O}_{7} \cdot 5 \mathrm{H}_{2} \mathrm{O}$ (anion destruction, amorphization of solid phase, anion condensation) occur fully. Thus, the degree of the diphosphate anion destruction reaches $34 \%$, when heating $\left(\mathrm{Mn}_{0.59} \mathrm{Co}_{0.41}\right)_{2} \mathrm{P}_{2} \mathrm{O}_{7} \cdot 5 \mathrm{H}_{2} \mathrm{O}$ up to $680 \mathrm{~K}$ (is equivalent to removal of 4.55 moles of $\mathrm{H}_{2} \mathrm{O}$ ). When treating $\left(\mathrm{Mn}_{0.85} \mathrm{CO}_{0.05}\right)_{2} \mathrm{P}_{2} \mathrm{O}_{7} \cdot 5 \mathrm{H}_{2} \mathrm{O}$ this stage of dehydration occurs at $590 \mathrm{~K}$ with the removal of 4.42 moles of $\mathrm{H}_{2} \mathrm{O}$ and it is accompanied by destruction of $28 \%$ of the diphosphate anions. Content of triphosphate in intermediate treating products of $\left(\mathrm{Mn}_{0.59} \mathrm{CO}_{0.41}\right)_{2} \mathrm{P}_{2} \mathrm{O}_{7} \cdot 5 \mathrm{H}_{2} \mathrm{O}$ is also higher. Temperature ranges of formation of the intermediates and the final product of dehydration $-\beta-\left(\mathrm{Mn}_{1-x} \mathrm{Co}_{x}\right)_{2} \mathrm{P}_{2} \mathrm{O}_{7}(0<x \leq 0.41)$ - with increasing content of $\mathrm{Co}(\mathrm{II})$ in $\left(\mathrm{Mn}_{1-x} \mathrm{Co}_{x}\right)_{2} \mathrm{P}_{2} \mathrm{O}_{7} \cdot 5 \mathrm{H}_{2} \mathrm{O} \quad(0<x \leq 0.41), \quad$ are shifted to $40-50$ degrees in direction of the higher temperatures.

Diphosphate $\beta-\left(\mathrm{Mn}_{1-x} \mathrm{Co}_{x}\right)_{2} \mathrm{P}_{2} \mathrm{O}_{7}(0<x \leq 0.41)$ is crystallized in monoclinic crystal system (space group $C 2 / m, Z=2$ ) with unit cell

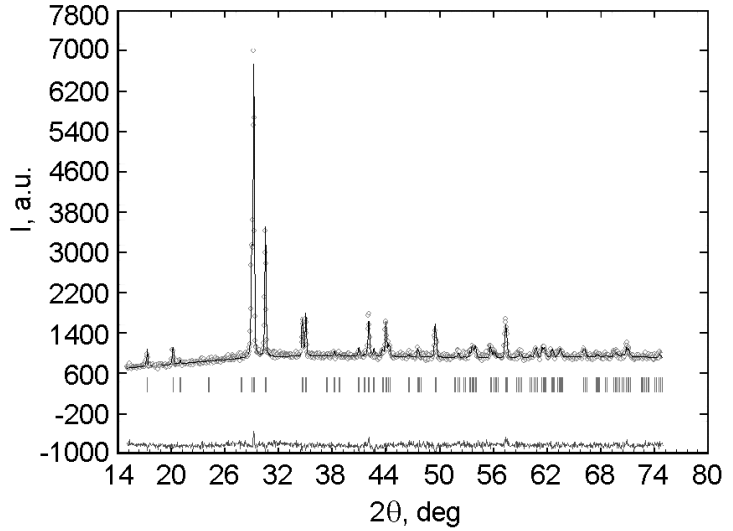

Fig. 3. Experimental (points), calculated (band) and resonant (lower band) diffraction profiles diphosphate of composition $\beta$ $\left(\mathrm{Mn}_{0.59} \mathrm{Co}_{0.41}\right)_{2} \mathrm{P}_{2} \mathrm{O}_{7}$.

parameters that vary according to the content of $\mathrm{Mn}^{2+}$ and $\mathrm{Co}^{2+}$ and values of their ionic radius (Table 2). They fit into a linear concentration dependence, describing formation of solid solution of the anhydrous diphosphate of composition $\beta-\left(\mathrm{Mn}_{1-x} \mathrm{Co}_{x}\right)_{2} \mathrm{P}_{2} \mathrm{O}_{7}$, $0<x \leq 0.41$.

Summarizing the data obtained, a principle diagram of a sequence of thermal and solid structural solidphase changes accompanying the heat treatment of the solid solution of diphosphate of composition $\left(\mathrm{Mn}_{1-x} \mathrm{Co}_{x}\right)_{2} \mathrm{P}_{2} \mathrm{O}_{7} \cdot 5 \mathrm{H}_{2} \mathrm{O}(0<x \leq 0.41)$, can be represented as follows shceme 2 .

Thus, formation of $\beta-\left(\mathrm{Mn}_{1-x} \mathrm{Co}_{x}\right)_{2} \mathrm{P}_{2} \mathrm{O}_{7} \cdot 5 \mathrm{H}_{2} \mathrm{O}$ $(0<x \leq 0.41)$ takes place simultaneously in two routes. The first one is implemented at 69-66 \% and provides the formation of $\beta$ $\left(\mathrm{Mn}_{1-x} \mathrm{Co}_{x}\right)_{2} \mathrm{P}_{2} \mathrm{O}_{7}$ as a result of the molecular mechanism of the crystal hydrated water removal. According to the second, which is at $31-34 \%$, the formation of $\beta-\left(\mathrm{Mn}_{1-x} \mathrm{Co}_{x}\right)_{2} \mathrm{P}_{2} \mathrm{O}_{7}$ is a result of the solidphase interactions of the intermediate treating products of $\left(\mathrm{Mn}_{1-x} \mathrm{Co}_{x}\right)_{2} \mathrm{P}_{2} \mathrm{O}_{7} \cdot 5 \mathrm{H}_{2} \mathrm{O}$. 


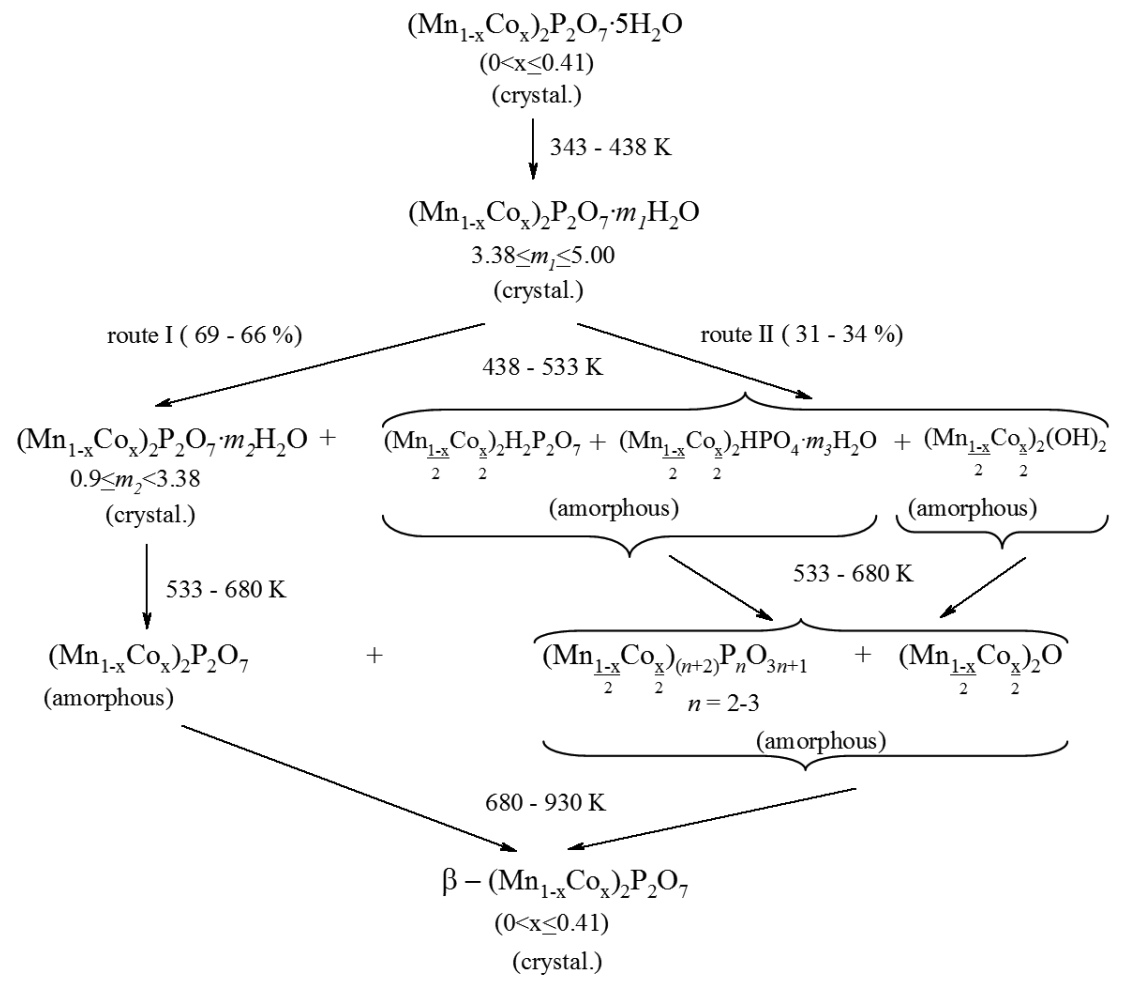

Sheme 2 .

\section{Conclusions}

Composition, temperature ranges of formation and thermal stability of solid solution thermal treatment products of general formula $\left(\mathrm{Mn}_{1-x} \mathrm{Co}_{x}\right)_{2} \mathrm{P}_{2} \mathrm{O}_{7} \cdot 5 \mathrm{H}_{2} \mathrm{O}(0<x \leq 0.41)$ in the range of $298-1273 \mathrm{~K}$ are determined by the cation nature.

Sequence of the processes occurring in the heat treatment products, their quality stay the same for diphosphate $\left(\mathrm{Mn}_{1-x} \mathrm{Co}_{x}\right)_{2} \mathrm{P}_{2} \mathrm{O}_{7} \cdot 5 \mathrm{H}_{2} \mathrm{O}(0<x \leq 0.41)$ of different composition. Change undergo in quantitative characteristics of the processes of anion destruction, amorphization of solid phase, anion condensation, that are better performed in the products of thermal treatment of diphosphate with the higher content of cobalt (II). The maximum degree of destruction of diphosphate anion during the heat treatment of $\left(\mathrm{Mn}_{1-x} \mathrm{Co}_{x}\right)_{2} \mathrm{P}_{2} \mathrm{O}_{7} \cdot 5 \mathrm{H}_{2} \mathrm{O}$ $(0<x \leq 0.41)$ with $x=0.05$ is $28 \%$, for diphosphate with $x=0.41$ - it reaches $34 \%$. The content of triphosphate in the intermediate products of the thermal treatment of $\left(\mathrm{Mn}_{0.59} \mathrm{Co}_{0.41}\right)_{2} \mathrm{P}_{2} \mathrm{O}_{7} \cdot 5 \mathrm{H}_{2} \mathrm{O}$ is also higher.

The final products of the heat treatment - solid solution of anhydrous diphosphate of $\quad \beta-\left(\mathrm{Mn}_{1-x} \mathrm{Co}_{x}\right)_{2} \mathrm{P}_{2} \mathrm{O}_{7} \cdot 5 \mathrm{H}_{2} \mathrm{O} \quad(0<x \leq 0.41)$ (space group $C 2 / m, Z=2$ ) - is formed simultaneously in two directions. The first one is performed at 69-66\% due to dehydration of initial crystallohydrates of $\left(\mathrm{Mn}_{1-x} \mathrm{Co}_{x}\right)_{2} \mathrm{P}_{2} \mathrm{O}_{7} \cdot 5 \mathrm{H}_{2} \mathrm{O}$. According to the second one, $31-34 \%$ of $\beta-\left(\mathrm{Mn}_{1-x} \mathrm{Co}_{x}\right)_{2} \mathrm{P}_{2} \mathrm{O}_{7}$ are formed as a result of solid phase interaction of the intermediate products of dehydration.

Temperature ranges of formation and thermal stability of the intermediates and final products of dehydration of $\left(\mathrm{Mn}_{1-x} \mathrm{Co}_{x}\right)_{2} \mathrm{P}_{2} \mathrm{O}_{7} \cdot 5 \mathrm{H}_{2} \mathrm{O}(0<x \leq 0.41)$ with increasing content of $\mathrm{Co}$ (II) in the diphosphate composition are moved by 40-50 degree to the higher temperatures.

\section{References}

1. T.Kanazawa, Inorganic Phosphate Materiales, Elsevier, New York (1989).

2. Y.Chang, N.E.Shi, S.Zhao et al., ACS Appl. Mater. Inter Faces, 34, 22534(2016).

3. S.I.Nishimura, M.Nakamura, R.Natsui, A.Yamada, J.Am.Chem.Soc., 132, 13596 (2010).

4. Robertson, Etude de Pigments Thermochromes Autour du Cobalt II. Material Chem- 
istry, Universite Sciences et Technologies, Bordeaux I (2010).

5. V.L.Karbivskyy, S.S.Smolyak, Yu.A.Zagorodniy et al., Nanosyst. Nanomater. Nanotechnol., 10, 123 (2012).

6. UA Patent 103275, (2015).

7. N.M.Antraptseva, N.V.Solod, Functional Materials, 22, 224 (2015).

8. N.M.Antraptseva, N.V.Tkachova, J.Appl. Chem., 82, 1153 (2009).

9. N.M.Antraptseva, N.V.Solod, V.A.Povshuk, Functional Materials, 22, 322 (2015).

10. M.V.Goloshchapov, B.V.Martynenko, Inorg. Materials, 12, 485 (1976).
11. JCPDS. Powder Diffraction File Inorganic Phases. Published by the JCPDS International Centre for Diffraction Data, Swarthmere, USA (1986).

12. T.Stefanidis, A.G.Nord, Acta Cryst., C40, 1995 (1984).

13. V.V.Pechkovskiy (Ed.), Atlas of IR Spectra of Phosphates: Condensed of Phosphates, Nauka, Moscow (1985) [in Russian].

14. K.Brouzi, A.Ennaciri, M.Harcharras, Phosphorus, Sulfur and Silicon and the Related Elements, 179, 1329 (2004). 